\title{
EFFECTIVENESS OF NYANTRIC LEARNING MODELS IN FIELD EXPERIENCE PRACTICE (PPL) FOR S1 STUDENTS OF EDUCATION AND MANPOWER EDUCATION INSTITUTIONS (LPTK)
}

\author{
Haryono \\ STKIP PGRI Ngawi, East Java, Indonesia
}

\begin{abstract}
The education and learning process rests on the role of the teacher. To meet the demands of globalization required professional teachers, the teacher is ready to use with a wide range of competencies competency mastery of pedagogy, professional competence, personal competence, as well as social competence. The purpose of this research is to formulate the steps in the Nyantrik model learning in PPL which can produce graduates of a Bachelor of Education (S1) Education Personnel Education Institute (LPTK) who have pedagogical, professional, personality, and social competences. Furthermore, this study wanted to determine the effectiveness of the Nyantrik model learning in PPL for undergraduate students of the Education Personnel Education Institute (LPTK).

The method used in this research is based on the data collected is qualitative which comes from the results of observations, questionnaires, and interviews, in addition to qualitative data, data is also collected in the form of quantitative data obtained from observation and analysis of documentation. As instrument is collecting data used in research and development are Observation, Questionnaire, Interview Guide and analysis Documentation. The results showed that the Nyantrik model learning is a learning model used in Field Experience Practices (PPL) for undergraduate students of the Educational Personnel Education Institute (LPTK) with an intensive teacher competency transformation process through imitation, identification, internalization, and externalization of their competencies. by Guru Pamong by applying the teachings of Ki Hajar Dewantara in both formal and informal situations. Furthermore, a test of the effectiveness of the Nyantrik model learning shows that the Nyantrik model learning is better and more effective than the Apprenticeship Learning Model in Field Experience Practice (PPL) in shaping teacher competencies for undergraduate students of the Education Personnel Education Institute (LPTK). Based on the results of the wide-scale field effectiveness test, it can be concluded that: "The Nyantrik model learning is very effectively applied to Field Experience Practices (PPL) in forming
\end{abstract}


Effectiveness of Nyantric Learning Models in Field Experience Practice (PPL) for S1 Students of Education and Manpower Education Institutions (LPTK)

teacher competencies for undergraduate students of the Education Personnel Education Institute (LPTK) ".

Key words: Competence, Nyantrik, Education, Field Experience Practice.

Cite this Article: Haryono, Effectiveness of Nyantric Learning Models in Field Experience Practice (PPL) for S1 Students of Education and Manpower Education Institutions (LPTK), International Journal of Management (IJM), 11(12), 2020, pp. 3333-3349.

http://iaeme.com/Home/issue/IJM?Volume=11\&Issue=12

\section{INTRODUCTION}

The education and learning process rests on the role of the teacher. To meet the demands of globalization required professional teachers, the teacher is ready to use with a wide range of competencies competency mastery of pedagogy, professional competence, personal competence, as well as social competence. To prepare prospective teachers who have various teacher competencies, LPTK colleges have a very heavy task. To form four teacher competence cannot be just by giving subjects a theory but must be supported by courses include Experience Practice program (PPL). Before students carry out PPL, students are required to pass all supporting courses (theory courses) and especially Micro Teaching courses.

Preliminary Study Results through interviews with the Head of SMK PGRI 6 Ngawi and Head of West SMAN 1 Magetan obtained information that there are still many new teachers (teachers beginners) that have minimal competence, both in the pedagogical competence, professional, personal, and social. Generally, novice teachers who have just graduated from the LPTK have minimal competence.

Field Experience Practices attended by LPTK undergraduate students with the apprenticeship model are currently felt to be less effective, especially in terms of time (length of practice / frequency of practice), guidance from Pamong teachers, guidance from Field Supervisors, practice places (schools where PPLs), work the same between practitioners, and the management system. The apprenticeship model is good to use today because it is practical in its management. The Apprenticeship model does not contain many risks related to student management and teaching schedules.

With some of the weaknesses of the Apprenticeship learning model, it has an impact on the lack of formation of teacher competence in students. For this reason, it is necessary to develop a better and more suitable learning model in order to maximize teacher competence. Therefore, in this study a Nyantrik model learning was developed which is expected to form the maximum teacher competence.

The Nyantrik model learning is a learning model used in Field Experience Practice (PPL) for undergraduate LPTK students with an intensive teacher competency transformation process through imitation, identification, internalization, and externalization of the competencies possessed by Pamong Teachers by applying the teachings of Ki Hajar Dewantara both in formal and informal situations. Students as Cantrik learn or study from Pamong Teachers (Begawan/Empu) who are already professional in the context of forming teacher competence. In the Nyantrik model learning, the value and character of students are very important for prepare prospective professional teachers who are ready to work in educational institutions.

Students who take PPL with the Nyantrik model learning are required to have high awareness, strong interest and motivation, obedience and obedience, so that they can establish intensive and harmonious communication with their Pamong Teachers to learn and absorb various teacher competencies maximally. Intensive and harmonious communication between 
students (Cantrik) and Pamong Teachers (Begawan) becomes a way and a means in the process of transforming teacher competencies that can result in the formation of more maximum teacher competencies.

On the other hand, the Pamong Teacher as a Clerk/Empu has a very dominant and very important role as a professional educator and mentor to form teacher competencies for students who are Nyantrik. Pamong teachers are required to have professionalism, patience, and high dedication in order to be able to educate and guide their Cantrik towards maximum mastery of teacher competence.

Under these conditions, which is the goal of this study was Formulate steps in the learning model Nyantrik at PPL to produce graduates of Bachelor of Education (S1) Institutions of Education Personnel (LPTK) which has a pedagogical, professional, personal, and social and s He continued, knowing the effectiveness of the Nyantrik model learning in PPL for undergraduate students of the Education Personnel Education Institute (LPTK) .

\section{THEORETICAL BASIS}

\subsection{Theory Study}

In the Theory Review section, respectively, will discuss: 1) Teacher Competence, 2) The Nature of Field Experience Practice (PPL), 3) Learning Models, 4) Nyantrik model learning, and 5) Relationship between Teacher Competence, PPL, and Model Nyantrik Learning.

\subsubsection{Teacher Competence}

For a profession, competence is a requirement, as is the teaching profession. The teacher is one of the factors and components that determine the success of the learning process. A teacher must have various competencies related to the duties he/she is carrying in order to carry out tasks professionally.

According to Usman and Hasanah (2005: 6), competence is the ability and skills and skills of a person with regard to their duties, positions and professions. Teacher competence is the skills and abilities as well as skills of a person who is tasked with educating students to have a noble and noble personality as stated in the goals of national education.

A competency is more than just knowledge and skills. It involves the ability to meet complex demands, by drawing on and mobilizing psychosocial resources (including skills and attitudes) in a particular context. For example, the ability to communicate effectively is a competency that may draw on an individual's knowledge of language, practical IT skills and attitudes towards those with whom he or she is communicating. (Competence is more than just knowledge and skills. It involves the ability to meet complex demands, by shaping and deploying psychosocial resources (including skills and attitudes) in a particular context. For example, the ability to communicate effectively is a competency that can describe individual knowledge of language, practice of IT skills and attitudes towards those with whom he communicates.) (www.oecd.org/edu/statistics/desecowww.deseco.admin.ch) (2003) DS Rychen and LH Salganik (eds.) downloaded: Tuesday, 17 March 2012.

Based on the above understanding, it can be concluded that competence is a skill that a person must have in terms of knowledge, skills, and attitudes as one of the conditions for doing a complex job, where these skills are produced through a relatively long process.

Teacher is a profession that demands competency ownership. Profession is a job that in carrying out its duties requires / demands expertise, uses scientific techniques, and high dedication. Expertise is obtained from the LPTK specifically for this purpose with an accountable curriculum. 
Effectiveness of Nyantric Learning Models in Field Experience Practice (PPL) for S1 Students of Education and Manpower Education Institutions (LPTK)

\subsubsection{The Nature of Field Experience Practices (PPL)}

Field Experience Practice is one of the curricular activities carried out by students which includes both teaching training and non-teaching teaching assignments in an integrated and guided manner to meet the requirements for the formation of the educational profession. (http: //pbingLPTK unlam.wordpress.com/prosProcedure-operasional-standar/ba-vi-praktekp Experience field). downloaded: March 10, 2012 at 20:25

PPL activities include: 1). Teaching practice in class that has been determined, 2). School administration practices which are the responsibility of the teacher, 3). Guidance and counseling practices as well as co-curricular and extracurricular activities that apply in training schools. (STKIP PGRI Ngawi. 2010: 15).

\subsubsection{Learning Model}

Model is defined as a conceptual framework that is used as a guide in carrying out an activity. The Learning Model is a conceptual framework that describes a systematic procedure for organizing learning experiences to achieve specific learning goals and serves as a guide for learning designers and teachers in planning and carrying out teaching and learning activities. (Toeti Soekamto, Udin Saripudin W., 1996: 78).

Gunter (2005: 67) defines: an instructional model is a step-by-step procedure that leads to specific learning outcomes. (The learning model is a step-by-step procedure that leads to specific learning outcomes). Joyce \& Weil (2004) define the learning model as a conceptual framework that is used as a guide in conducting learning. Thus, the learning model is a conceptual framework that describes a systematic procedure for organizing learning experiences to achieve learning goals. So, the learning model tends to be prescriptive, which is relatively difficult to distinguish from the learning strategy.

From some of the definitions of the Learning Model above, it can be concluded that what is meant by a Learning Model is a conceptual framework as a guide in carrying out learning that describes a systematic step-by-step procedure in organizing learning experiences to achieve the desired learning goals.

In this development research, a learning model will be developed that is related to the formation of teacher competencies, named pedagogic, professional, personality, and social competencies. The learning model to be developed is the Nyantrik model learning in PPL for LPTK undergraduate students.

\subsubsection{Nyantrik model learning}

\subsubsection{The Nature of Nyantrik}

In the Javanese dictionary "Cantrik means abdining pandhita ngiras dadi pupil; Nyantrik: ngabdi marang pandhita" (Development Team for the Yogyakarta Language Center, 2002: 9394). Another opinion said that "Cantrik: students, pupils, santri at the hermitage." (Purwadi, 2004: 66). Nyantrik: studied, became a cantrik. Cantrik comes from the Javanese language which means pupil or student. Becoming a cantrik or nyantrik is often known in Javanese society as a process that one must go through before they are ready to become a leader or royal retainer.

Tjantrik (female: mentrik), for the level of "Taman-Guru" or our teachers who come out of other schools, then enter into our circles with the leadership of one of the leaders, who has got the right to educate tjantrik; the performance of the charm depends on his intelligence, knowledge, and the jantrik's customs. (Ki Hajar Dewantara, 1962: 115) 


\subsubsection{Basic Implementation of Nyantrik}

Character education can be done through the Nyantrik system with the example of educators and the obedience of the educated. Character education requires a harmonious and conducive educational situation. With the example of the teacher or educator, it is hoped that they can form noble character and character in students. The Nyantrik system demands obedience and obedience from students to their masters (Pamongnya teachers). With this obedience and obedience, it will be easy to form teacher competence, inculcate values, build character, good traits and noble morals in students.

In the education system there is a process, named the transformation process. What is meant by the process of transformation in the education system is converting inputs into outputs or processing inputs into outputs. According to Soenarwan (2008: 20) states that: "An open system must receive input from the external environment which after processing will come out in the form of output received by the external environment. In other words, the open system has the characteristic of importing input and exporting output.

In the Nyantrik model learning what is meant by the transformation process is processing input, named students practicing by applying the Nyantrik model learning to produce output, named the output of students who have teacher competence.

\subsubsection{Competency Transformation Process in Nyantrik model learning}

- Competency Transformation Process through Imitation, Identification, Internalization, and Externalization

According to Salim \& Salim (2001: 218), in the learning process of material transformation and competence, the psychological involvement experienced by educators includes at least four stages, named through:

- Imitation is the process of imitating the actions of others as if they were imitated. Imitation only adopts or duplicates one aspect or one kind of simple behavior from the idol.

- Identification is imitation or imitation as a whole, named the tendency to imitate various kinds of characteristics and behavior of others. Identification is different from imitation, because imitation only adopts one kind of aspect or one kind of behavior, whereas identification adopts as a whole.

- Internalization is an effort to unite the values that are instilled in him as part of his personality.

- Externalization or actualization of what has been imitated, identified and internalized in a person will be manifested in the form of behavior. This behavior as a form of self-actualization is a reflection of the learning outcomes experienced by educators, both from the process of imitation, identification, and internalization.

- Competency Transformation Process through Ki Hajar Dewantara's Teachings

In the process of educating a civilian as a leader, he must have the following attitude: Ing ngarsa sung tuladha, Ing madya mangun karsa, Tut wuri handayani. A tutor as an educator is essentially obliged to be a role model for his students by providing positive examples in his daily life. He must be consistent and consistent in his behavior or only in words and actions (Ngerti-Ngrasa-Nglakoni). This pamong example is important, because it will influence the character building of students. (Ki Hariyadi, 1985: 16)

In another part, Ki Hariyadi stated: Pamong is not allowed to be authoritarian towards their students and must act as Ing ngarsa sung tuladha, Ing madya mangun karsa, and Tut wuri handayani. The Pamong is guiding and when students deviate from the limits of their 
Effectiveness of Nyantric Learning Models in Field Experience Practice (PPL) for S1 Students of Education and Manpower Education Institutions (LPTK)

independence, the Pamong gives influence or authority. Therefore, the Among method tries to raise the enthusiasm and activities of students. (Ki Hariyadi, 1985: 22-23).

\subsubsection{The relationship between Teacher Competence, Field Experience Practice, and Nyantrik model learning.}

The Nyantrik model learning as a solution to overcome the weaknesses and shortcomings of the Apprenticeship learning model is packaged with steps that are easy to implement, with harmonious and familial situations and conditions. With situations and conditions that are harmonious and kinship, students can communicate and interact as well as possible in the mentoring process. As long as students take PPL there are many obstacles and problems they face. For this reason, a forum is provided to discuss problems and find solutions in the form of periodic workshops. The results of the workshop can be used as a reference and a basis for further teaching practice, so that mistakes will not be repeated and it is hoped that there will always be improvements from day to day towards achieving maximum results in the formation of teacher competencies.

\section{RESEARCH METHODS}

The research carried out was a Research and Development (R \& D). Development research is an effort to develop and produce a product in the form of materials, media, or learning strategies that are used to solve problems in the classroom or laboratory, and not to test theories (Soenarto, 2005: 1). The Research and Development ( $\&$ \& D) carried out is to produce a product in the form of a Learning Model used in PPL for LPTK undergraduate students. The development of this Learning Model is very important in an effort to improve teacher competence that LPTK undergraduate students must possess so that one day they can become professional teachers in accordance with the demands of the times. The learning model developed is called the Nyantrik model learning.

The data collected is qualitative in nature derived from observations, questionnaires, and interviews, in addition to qualitative data, it is also collected in the form of quantitative data obtained from observation and documentation analysis. As instrument is collecting data used in research and development are Observation, Questionnaire, Interview Guide and analysis Documentation. Furthermore, the analysis of data processing is carried out by referring to the definition according to Miles and Huberman (in Sugiyono, 2007: 246). Qualitative data analysis is carried out interactively and continuously with the following steps: Data reduction, data presentation (Data display), and inference and verification (conclusion drawing/verification). Comparing the final value of the PPL Nyantrik model learning with the value of the Apprenticeship Learning Model. The Nyantrik model learning is said to be effective if the results of the broad-scale field test obtain a t-test value that is different or greater than the Apprenticeship Learning Model in the formation of teacher competence in student practitioners. Data processing uses the help of SPSS-17 software.

\section{RESULTS AND DISCUSSION}

\subsection{Research Data Analysis}

\subsubsection{Apprenticeship Learning Model in PPL}

Based on the results of the Preliminary Study, it can be stated that the teacher competence formed by the Apprenticeship learning model is not optimal. This is evidenced by the final average value of PPL 78.82. With this average value, it shows that the mastery of teacher competence by applying the apprenticeship learning model is not satisfactory and not optimal. 
Based on the results of the Preliminary Study, things related to the apprenticeship learning model can be stated as follows:

- The advantages of the Apprenticeship learning model in PPL are:

- Practical and easy to manage because it has been done routinely for years.

- The time for implementing PPL is short, named between one month to two months, thus saving costs.

- The placement of students in schools where they practice is determined by the UPT PPL so that it is easier to handle.

- The weaknesses that exist in the Apprenticeship learning model in PPL are:

- The formation of teacher competence in students has not been maximized due to the lack of frequency of practical teaching exercises in schools where PPL is located.

- The personal relationship between students and the tutor is less intensive.

- The relationship between students and field supervisors is also less intensive.

- There is no discussion forum that can be used to discuss problems faced by students.

○ Guidance from the tutor is only carried out in the school where the practice is during effective hours.

- To overcome some of the weaknesses in the Apprenticeship model, it is necessary to develop a new, more effective learning model in order to maximize teacher competency, named the Nyantrik model learning.

\subsubsection{Test Expert (Expert Judgment)}

\subsubsection{Initial Product}

\subsection{Concept of Nyantrik model learning}

The Nyantrik model learning is a learning model used in Field Experience Practices (PPL) for undergraduate students of the Educational Personnel Education Institute (LPTK) with an intensive teacher competency transformation process through imitation, identification, internalization, and externalization of the competencies possessed by Pamong Teachers by implementing teachings of Ki Hajar Dewantara in both formal and informal situations. The intensive mentoring process from Pamong Teachers is carried out both at school (effective school hours) and outside of school (outside effective hours) in the framework of forming teacher competency. The mentoring process is intensively carried out face-to-face or by using Information and Communication Technology such as Mobile (HP) and the Internet or Blanded Learning.

\subsubsection{Expert Judgment}

The Nyantrik model learning was tested and verified by two education experts, especially in the field of Field Experience Practice. The initial model was tested and verified by the two experts with the following results: 1) The Nyantrik model learning needs to be revised by adding elements of periodic workshops every two weeks, 2) Increasing the frequency of modeling from tutor teachers, 3) Testing the effectiveness of the model is done qualitatively individualistic for every student who takes PPL with the Nyantrik model learning . After being revised based on the results of testing and verification from experts, then a limited field trial was carried out. 
Effectiveness of Nyantric Learning Models in Field Experience Practice (PPL) for S1 Students of Education and Manpower Education Institutions (LPTK)

\subsubsection{Test of the Effectiveness of the Nyantrik model learning}

The test of the effectiveness of the Nyantrik model learning is carried out in accordance with the sequence of steps that have been stated in the front. Analysis of research data related to the Effectiveness Test of the Nyantrik model learning are as follows:

\subsubsection{Results of Teacher Competency Observation in Competency Transformation Process through Imitation and Identification}

Assessment of the competency transformation process through imitation, identification, and internalization is carried out by the tutor teacher after modeling from the tutor teacher. The assessment is carried out by the observation method of all students practicing sample members who are carrying out teaching practices.

The indicators for assessing the process of competency transformation through imitation are: 1) How to open lessons, 2) How to give perceptions, 3) How to motivate students, 4) Explain or provide explanations, 5) Ask students' techniques, 6) Manage discussions, 7) Apply methods certain, 8) Applying learning media, 9) How to make conclusions, 10) How to make variations, 11) How to conduct an evaluation, and 12) How to close the lesson.

The indicators for the assessment of the competency transformation process through identification are: 1) Skills in applying certain learning methods from start to finish, 2) Skills in managing the class with the situations and characteristics of the students being faced, 3) Skills related to the use of learning media, 4) Competence related to the formation of patience, dignity, and exemplary.

Based on the recapitulation table it can be said that the absorption of teacher competence through Imitation and Identification can be done by students with the predicate "Good." This shows that the process of transforming teacher competence through imitation and identification in the Nyantrik model learning can shape teacher competence in students well. In accordance with what was stated by Salim \& Salim (2001), imitation can happen well if someone's behavior depends on someone who is smarter. The behavior of the first person (Cantrik) can be formed according to the behavior of the second person (Guru pamong / Begawan / Empu). In the Nyantrik model learning, the process of teacher competency transformation occurs through imitation, in which students imitate a small portion of the professional tutelage behavior to be applied to teaching practice. What has been exemplified by the tutor can be practiced by students in teaching practice in class.

\subsubsection{Results of the RPP Assessment and Teaching Practice}

Before carrying out the learning process, students are required to prepare a Learning Implementation Plan (RPP). In this research, the Pamong Teacher carried out an assessment of the students' abilities in compiling lesson plans and teaching practices periodically four times. At the end of the PPL, the PPL Examination was held with examiners of Pamong Teachers and Field Supervisors.

Based on the Recapitulation Table, the following discussion can be stated:

a) Assessment of RPP preparation and teaching practices carried out by Pamong Teachers, named four times during teaching practice and once for PPL exams. The results of the assessment from the Pamong Teachers show that the formation of teacher competencies in preparing lesson plans and implementing learning has increased significantly from the first to the fourth period. In detail can be seen in Table 1 below: 


\section{Table 1}

\begin{tabular}{|c|c|c|c|}
\hline I & II & III & IV \\
\hline $\mathbf{7 0 . 9 5}$ & $\mathbf{7 4 . 9 9}$ & $\mathbf{7 9 . 2 9}$ & $\mathbf{8 3 . 7 2}$ \\
\hline
\end{tabular}

In the first period the average value obtained was 70.95 , an increase in the second period by 74.99 , there was an increase in value by 4.04 . In the third period the average value was 79.29 , there was an increase compared to the second period of 4.3. In the fourth period the average value was 83.72 , an increase of 4.43 compared to the third period. The increase in mastery of competencies, especially in the preparation of lesson plans and implementation of learning, is due to intensive guidance from the Pamong Teachers and Field Supervisors. This is in accordance with the learning theory of Behaviorism (Toeti Soekamto: 1996) which says that if the stimulus is repeated, a steady response is formed. The more teaching frequency carried out by students, the better the competence they will master. Learning is the result of interaction between Stimulate and Response (Slavin, 2000: 143). A person is considered to have learned something if he can show a change in behavior. According to this theory, what is important in learning is input in the form of a stimulus and output in the form of a response. In relation to mastering teacher competence through internalization, students can master teacher competence with intensive and repeated guidance from their tutor teachers.

The increase in teacher competency mastery is also due to the regular workshop every two weeks. All problems faced by students when compiling lesson plans and implementing learning were brought up during the workshop to find solutions to solve them, so that they would not be repeated in subsequent practical periods. The results of the workshop are used as a basis and basis for designing lesson plans and implementing further learning. Thus, there is a periodic formation and improvement of competence in each practice. In line with the research results of Robert Rueda and Lilia D. Monzo (2002), named collaboration between teachers and prospective teachers in discussions / brainstorming can improve teacher competency mastery.

b) There was an increase in the ability of students in preparing lesson plans and teaching practices from the first period to the fourth period and on the PPL Examinations both from the Pamong Teacher and from the Field Supervisory Lecturers, which is indicated by the average value as shown in Table 2 :

Table 2

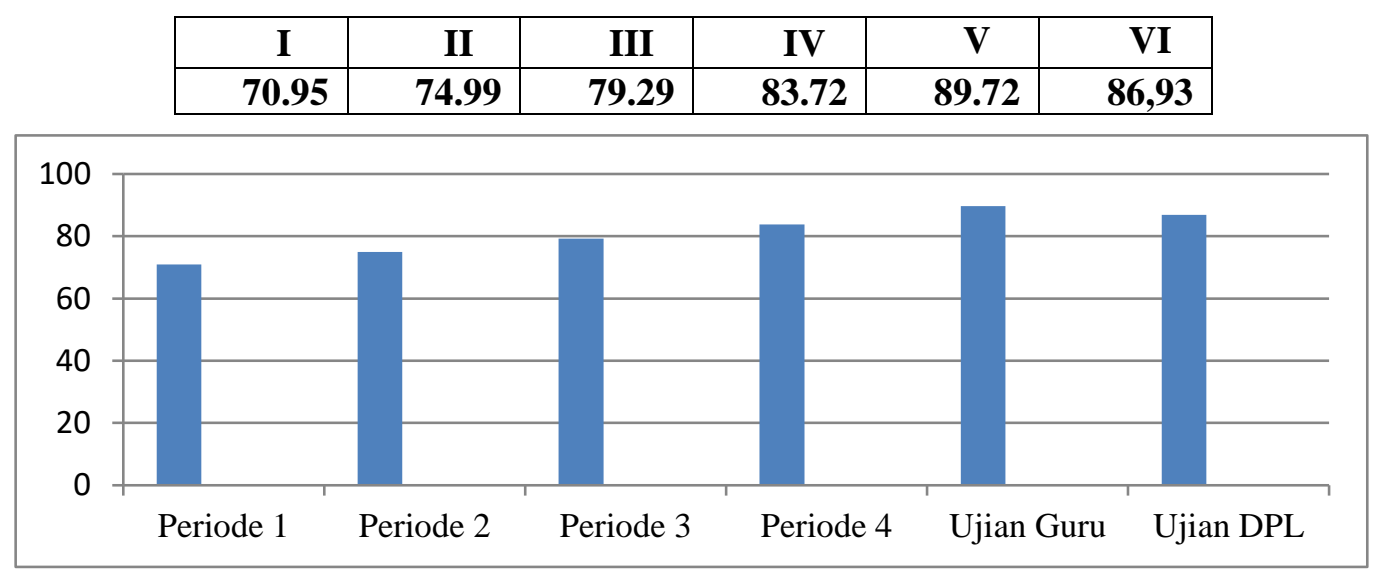

Figure 1

From Table 2 it can be presented in the form of Figure 1 below:

Figure 1. Improved Ability an RPP Students in Developing and Teaching Practice

Based on Figure 1 shows that the application of the Nyantrik model learning can form teacher competence gradually and sustainably well, so as to achieve maximum results. This is 
Effectiveness of Nyantric Learning Models in Field Experience Practice (PPL) for S1 Students of Education and Manpower Education Institutions (LPTK)

evidenced by an increase from the first period to the fourth period and the end of the exam. The final average score of the pamong and DPL teachers was 88.33. This shows that the level of mastery of competence reaches the predicate "Very Satisfying." Increased mastery of competence, especially in the preparation of lesson plans and implementation of learning due to intensive guidance from Pamong Teachers and Field Supervisors both at school and outside of school.

\subsubsection{Questionnaire Results for Nyantrik model learning at the Beginning and End of PPL}

In the early PPL period, all student members of the research sample were given a questionnaire about the Nyantrik model learning. The aim is to find out the students' responses and responses to the Nyantrik model learning that will be applied during the Field Experience Practice.

In the final PPL period all student members of the research sample were given a questionnaire about the Nyantrik model learning. The aim is to determine the responses and responses of students to the Nyantrik model learning that has been applied during the Field Experience Practice.

There was a very significant change in student responses to the application of the Nyantrik model learning at the beginning of PPL and at the end of PPL. Of all the questionnaire statements totaling 20 items, in the initial period of students who stated "Disagree" there were $27.63 \%$ and in the final period being zero percent meant a change of $27.63 \%$. In the initial period, there were $55.53 \%$ stated "doubt" and in the final period $0.79 \%$ there was a change of $54.74 \%$. In the initial period, students who stated "Agree" were $16.58 \%$ and in the final period there were $46.9 \%$, meaning there was an increase of $33.32 \%$. In the initial period which stated "Strongly Agree" there was $0.26 \%$ and in the final period it was $52.31 \%$ there was an increase of $52.05 \%$.

The change and increase in the percentage in the Questionnaire statement of the Nyantrik model learning is because students feel suitable with the application of the Nyantrik model learning when implementing Field Experience Practices. The application of the Nyantrik model learning can form a maximum and very satisfying teacher competence in students.

\subsubsection{Results of Periodical Workshops Every Two Weeks}

Periodic workshops which are held once every two weeks are a place and a place for students to share all the problems faced during PPL. Pamong teachers and field supervisors try to help and guide students in finding solutions to any problems they face. Various forms of solutions provided by the supervisor, become provisions for students to move better in the next practice.

Regular workshops are also used by students to strengthen ties and kinship, both with Pamong Teachers, Field Supervisors, and with fellow students. With the establishment of a good and intensive relationship between students and their Pamong teachers, harmonious communication occurs in the mentoring process. Students feel that there is no gap and distance between themselves and their Pamong Teachers, in other words, there is pleasant personal communication. In these conditions, students can optimally form competences in themselves as expected.

\subsubsection{Results of Teacher Competency Observation}

Assessment using the observation method of the formation of teacher competence is carried out by the Pamong teacher periodically three times, named twice when the student is still practicing and once at the end of PPL. Observations were also made by Field Supervisors (DPL) at the end of PPL. 
Based on the recapitulation table, the following discussion can be stated: The results of the observation of teacher competence carried out by the Pamong teacher twice during the learning practice and once at the end of PPL showed an increase in the formation of teacher competence. The results of observations from the Pamong and DPL teachers show that the formation of teacher competencies, especially those related to the formation of four teacher competencies, has increased significantly from the first period to the PPL exam period. In detail can be seen in Table 3 below:

Table 3

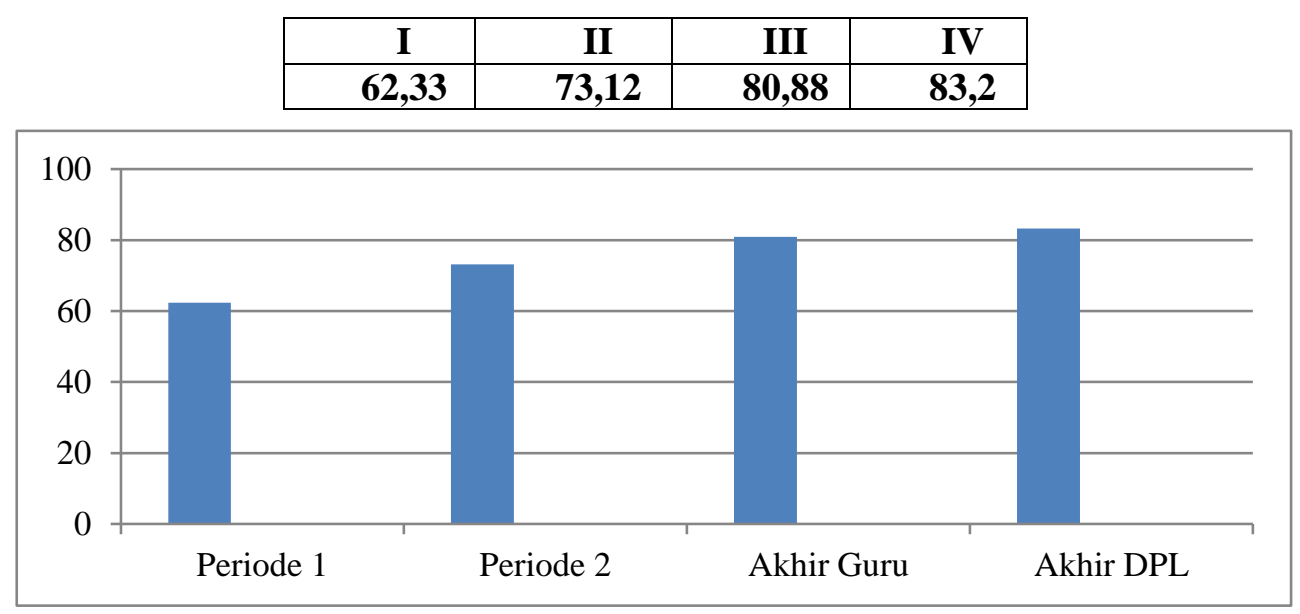

Figure 2

From Table 3 it can be presented in the form of Figure 2 as follows:

Figure 2. Increased Mastery Competence Teaching

Based on the histogram graphic above, it can be concluded that the application of the Nyantrik model learning can form four teacher competencies gradually and continuously well so as to achieve maximum results. This is evidenced by an increase in the average value in each period. In the first period the average value increased to 62.33 to 73.12 in the second period, an increase of 10.79. In the third or final period of PPL, the assessment of the Pamong Teachers increased again to 80.88 , an increase compared to the second period, named 7.76. When compared with the average value of the DPL, which is 83.2, there is an increase of 10.08 compared to the average value in the second period. The average score at the end of the PPL between the Pamong Teacher and DPL was 82.04, which was very satisfying. This shows that the Nyantrik model learning is very effective in forming teacher competence for undergraduate students of the Education Personnel Education Institute (LPTK).

\subsubsection{Final Value of Field Experience Practice (PPL)}

To determine the final PPL score, it is obtained by finding the average value between the final value of RPP preparation, learning implementation, and overall mastery of teacher competencies.

In accordance with the data in the table, it shows that 95\% (18 students) who took PPL with Nyantrik scored $<80$ with a very good graduation predicate and only $5 \%$ obtained a score below 80 with a good predicate. In the apprenticeship model, only $26 \%$ (5 students) who took the PPL with the apprenticeship got a score of $<80$ with a very good graduation predicate and most of the $74 \%$ students (14 students) who obtained grades below 80 with good predicate Judging from the final average value of the PPL Nyantrik model learning is 85.48 and the final value of the PPL Apprenticeship Learning Model is 78.82. This shows that the average score of Nyantrik is higher than that of internships. Based on data processing with SPSS-17, the t-test value was 
Effectiveness of Nyantric Learning Models in Field Experience Practice (PPL) for S1 Students of Education and Manpower Education Institutions (LPTK)

11,705 and the t-table was 7,8523. There is a significant difference between the Nyantrik model learning and the Apprenticeship Learning Model. Judging from the magnitude of the average value, the Nyantrik model learning is more effective than the Apprenticeship Learning Model.

Based on all the research data analysis above, it can be argued that: "The Nyantrik model learning is better and more effective than the Apprenticeship Learning Model in Field Experience Practice (PPL) in shaping teacher competence for undergraduate students of the Education Personnel Education Institute (LPTK)."

\subsection{Advantages of Nyantrik model learning}

Based on the results of the effectiveness test that has been carried out, the Nyantrik model learning has advantages. The advantages of the Nyantrik model learning are:

- Students as Cantrik can learn from professional Pamong Teachers (Begawan / Empu) intensively. Cantrik who is always obedient and obedient to the pamong teacher has high motivation to master teacher competence in accordance with the competencies possessed by the tutor teacher.

- Students have sufficient time to consult and receive intensive guidance from the tutor group, so that they can master teacher competencies to the maximum.

- With modeling from the tutor, students can absorb various competencies / skills through imitation, identification and internalization which are then externalized or actualized in the form of learning practices, so as to increase the level of mastery of teacher competencies.

- With the application of Ki Hajar Dewantara's teachings, students can form good values and character by imitating the good and noble behavior of the tutor teacher, gaining motivation and encouragement in practice, and obtaining moral support from the tutor teacher so that it greatly supports the mastery of teacher competence.

- The combination of formal and informal Nyantrik adds to the opportunity for students to communicate and interact intensively with their tutors, so that the mentoring process can run well in the framework of forming teacher competence.

- With regular workshops every two weeks students can get solutions to problems encountered during practice and can improve in subsequent practices.

- The use of Information and Communication Technology channels such as the Internet and Mobile (HP) students can be more flexible in communicating and consulting with civil servants in maximizing their mastery of teacher competencies.

\subsection{Guarantee System for Product Implementation}

The Guarantee System for Product Implementation can be implemented by first providing socialization and introduction to the Nyantrik model learning to all relevant stakeholders, especially student practitioners and Pamong Teachers by the PPL Technical Implementation Unit (UPT) at the LPTK. The PPL Technical Implementation Unit (UPT) at the LPTK as the manager and implementer of PPL has the task of giving explanations to Pamong Students and Teachers about the steps that must be carried out in applying the Nyantrik model learning.

The Nyantrik model learning generated from this development research can be implemented in Field Experience Practices (PPL) at the Educational Personnel Education Institute (LPTK) with the following requirements: 
Haryono

\subsubsection{Requirements for Students}

Students who take PPL with the Nyantrik model learning must meet the following requirements:

- Fulfill the administrative and academic requirements in accordance with the provisions of the UPT PPL.

- Have a sincere intention and high awareness for suwita or learn from tutoring teachers.

- Have high interest and motivation to take PPL with the Nyantrik model learning.

- Willing to follow the steps in consistently applying Nyantrik model learning.

- Willing to establish intensive communication with pamong teachers in both formal and informal situations.

- Mean serious in carrying out any activity in the effort mastery learning in teacher competence, the planting of the value (value) and the formation of character.

\subsubsection{Requirements for Pamong Teachers}

Pamong teachers who guide PPL with the Nyantrik model learning must meet the following requirements:

- Permanent Foundation Teachers or Civil Servants (PNS)

- Have a minimum S1 diploma

- Have a minimum service period of 10 years

- Have an Educator Certificate (Already Certified)

- Obtaining recommendations from the Principal of the workplace

- Willing to guide students with good and earnest

- In accordance with the practical student study program

- Willing to act as Begawan or a professor in the application of learning models Nyantrik.

\subsection{Product Revisions}

After going through the effectiveness test of the Nyantrik model learning by analyzing research data and discussing the research results that have been stated above, the Nyantrik model learning needs to be revised. By observing step by step from the beginning to the end of the PPL implementation with the Nyantrik model learning, there are several things that need to be revised and added, named:

- Before students take PPL, they need to be given an explanation by the UPT PPL about the application of the Nyantrik model learning. Explanations can be given when students take Micro Teaching courses.

- Before PPL was implemented the UPT PPL gathered all Field Supervisors and Pamong Teachers to discuss the implementation of the Nyantrik model learning in PPL to be implemented.

- When a student carries out a teaching practice, other students in one group can make observations using the observation guidelines that have been prepared to assess and correct the ongoing learning process and to enrich the learning repertoire.

\subsection{Final Product Assessment}

Based on the research results, research data analysis and product revisions above, it can be stated that the final product study is as follows: 
Effectiveness of Nyantric Learning Models in Field Experience Practice (PPL) for S1 Students of Education and Manpower Education Institutions (LPTK)

- The Nyantrik model learning that has been tested for its effectiveness and has been revised can be applied to Field Experience Practices for undergraduate students of the Education Personnel Education Institute (LPTK).

The Learning Model Nyantrik as a final product with the syntax as follows:

○ Briefing for Students

Before the implementation of PPL with the Nyantrik model learning UPT PPL held debriefing with the aim that students who practiced get an overview and get to know the Nyantrik model learning that will be used in PPL.

○ Coordination Meeting between UPT PPL with field supervisors and tutors.

Prior to the implementation of PPL, the UPT PPL held a coordination meeting with the DPL and civil service teachers to obtain a common perception in implementing the Nyantrik model learning that will be used during PPL.

- Observation and School Orientation Practice Place

Starting PPL with the Nyantrik model learning, students conduct observations and orientation of the school where they practice with the aim that students who practice it get an overview and get to know the situation and conditions of the school that will be used for PPL.

○ Modeling from the Pamong Teacher

When the tutor teacher displays modeling, students make observations of the tutoring teacher modeling with the aim that students practice acquire knowledge and skills related to teacher competence, especially basic teaching skills.

- Students do Transformation Knowledge, Value (attitude), and Skill in Intensive through imitation, identification, Internalizing and Externalizing

The observation results of the tutor teacher modeling are imitated, identified, internalized, and externalized by the students in teaching practice in the classroom according to their respective fields of study.

- Values and Character Building Based on Ing ngarsa sung tuladha, Ing madya mangun karsa, and Tut wuri handayani

The formation of teacher competence through PPL with the Nyantrik model learning emphasizes the inculcation of values and character education through the exemplary of pamong teachers by applying the teachings of Ki Hajar Dewantara, named Ing ngarsa sung tuladha, Ing madya mangun karsa, and Tut wuri handayani.

\section{$\circ$ Learning Nyantrik F ormal and Nyantrik Inf ormal}

The process of mentoring students by tutor teachers is carried out intensively with guidance books / cards both in schools during effective school hours (formal Nyantrik ) and outside of school or outside effective hours ( Nyantrik Informal). Students have ample time to communicate, interact, and consult with civil service teachers on matters related to PPL in formal situations at school and informal situations outside of school.

○ Periodic Workshop every Two Weeks and Intensive Interaction with Information and Communication Technology

Periodic workshops are held every two weeks attended by students in one group, Pamong Teachers, and Field Supervisors to discuss problems faced by students while undergoing PPL. Tutor teachers can provide corrections, evaluations, and solutions to problems faced by students. The results of the workshop are used as a basis for improving planning and implementing future teaching practices. 
The process of mentoring and forming teacher competencies is also carried out intensively by utilizing Information and Communication Technology (ICT) to make it more effective and efficient in efforts to form the maximum teacher competence.

- The Nyantrik model learning which has unique specifications is expected to be used to form maximum teacher competence for students of the Education Personnel Education Institute (LPTK).

- The Nyantrik model learning can be disseminated to all stakeholders, whether it is directly related to the formation of teacher competencies for LPTK undergraduate students and policy makers.

- The final product of this development research is the Nyantrik model learning with its Implementation Guide.

\section{CONCLUSION}

Based on the description of the discussion, it can be concluded that:

The Nyantrik model learning is a learning model used in Field Experience Practices (PPL) for undergraduate students of the Educational Personnel Education Institute (LPTK) with an intensive teacher competency transformation process through imitation, identification, internalization, and externalization of the competencies possessed by Pamong Teachers by implementing teachings of Ki Hajar Dewantara in both formal and informal situations.

Testing of the effectiveness of the Nyantrik model learning shows that the Nyantrik model learning is better and more effective than the Apprenticeship Learning Model in Field Experience Practice (PPL) in shaping teacher competence for undergraduate students of the Education Personnel Education Institute (LPTK). Based on the results of the wide-scale field effectiveness test, it can be concluded that: "The Nyantrik model learning is very effectively applied to Field Experience Practices (PPL) in forming teacher competencies for undergraduate students of the Education Personnel Education Institute (LPTK)".

\section{REFERENCES}

[1] Abdul Majid. 2007. Learning Planning Develops Teacher Competency Standards. Bandung: PT Remaja Rosdakarya.

[2] Anderson, Lorin W and Krathwohl, David R. 2001. A Taxonomy for Learning, Teaching, and Assessing, A Revision of Bloom's Taxonomy of Educational Objectives. New York: Longman Inc.

[3] Asmawi Zainul and Noehi Nasution. 2001. Assessment of Learning Outcomes. Jakarta: PPUT Dirjen Dikti Depdiknas.

[4] Atwi Suparman, M. 2001. Instructional Design. Jakarta: PPUT Dirjen Dikti Depdiknas.

[5] Bloom, Benjamin S. 1956. Taxonomy of Educational Objectives: Handbook 1, Cognitive Domain. New York: David McKay.

[6] Borg, WR and Gall, MD 2007. Educational Research: An Introduction. Eighth Edition. London: Longman, Inc.

[7] Creswell JW, 1994, Research Design: Qualitative and Quantitative Approaches. Sage Publication: Thousen Oaks.

[8] Dick, W. And Carey, L. (1996). The Systematic Design of Instruction. New York: Harper Collin Publishers. 
Effectiveness of Nyantric Learning Models in Field Experience Practice (PPL) for S1 Students of Education and Manpower Education Institutions (LPTK)

[9] Ngawi District Education Office. 2003. Law of the Republic of Indonesia No. 20 of 2003 concerning the National Education System. Ngawi: tp

[10] Erickson, Gaalen. 2005. Collaborative teacher learning: Findings from two professional development projects. Journal of Teaching and Teacher Education 21 (2005) 787-798. (http://www.elsevier.com/ locate / tate). E-mail: Tate @ cardiff. ac.uk accessed on Wednesday, January 12, 2011 at 9:10 p.m.

[11] Evan M. Glazer, Michael J. Hannafin. 2006. The collaborative apprenticeship model: Situated professional development within school settings. Journal of Teaching and Teacher Education 22 (2006) 179-193. www.elsevier.com/ locate / tate. Accessed Thursday, December 30, 2010 at 15.00

[12] Furqon Hidayatullah, M. 2007. Introducing Prospective Educators with Character in the Future. Surakarta: Sebelas Maret University Press and Cakra Books.

[13] Glazer and Hannafin. 2006. The collaborative apprenticeship model: Situated professional development within school settings. Journal Teaching and Teacher Education. 22. 179-193.

[14] Gulo, W. 2005. Teaching and Learning Strategies. Jakarta: Grasindo

[15] Husaini Usman. 2009. Management Theory, Practice, and Educational Research. Edition 3. Jakarta: Earth Literacy.

[16] Hyo-Jeong So, Bosung Kim. 2009: Learning about problem based on learning: Student teachers integrating technology, pedagogy and content knowledge. Australasian Journal of Educational Technology 2009, 25 (1), 101-116. http://www.asian-efl-journal.com/Sept_ 09_dn.php. Accessed Monday, December 27, 2010 at 15:45

[17] Januszewski, Alan and Michael Molenda. 2008. Educational Technology, A Definition with Commentary. New York: Lawrence Erlbaum Associates.

[18] James Venema \& Russell Notestine. 2006. A Task-Based Curriculum for Homestay Students. http: //www.asian-efl-journal. com /Sept_06_dn.php. accessed March 2012.

[19] John M. Ritz. 2009. A New Generation of Goals for Technology Education. Journal of Technology Education Vol. 20 No. 2, Spring 2009. (jritz@odu.edu). http://www.collectionscanada.ca/obj/s4/f2/dsk3/ftp04/ MQ61574.pdf. Diakes Wednesday, January 12,2011 at $21: 25$

[20] John Loughran, Amanda Berry. 2005. Modeling by teacher educators. Monash University, Wellington Road, Clayton VIC 3168, Australia. Journal of Teaching and Teacher Education 21 (2005) 193-203. http://iteslj.org/Lessons/ Amelsvoort-PreDeparture.html. Accessed Tuesday, January 4, 2011 at 8:25 p.m.

[21] Head of UPT PP UNS. 2012. Practical Field Experience. Surakarta: (http: //ppl.LPTK. Uns.ac.id/ppl, accessed in May 2012).

[22] Khvilon, Evgueni \& Patru, Mariana. 2002. Information and Communication Technology in Education, A Curriculum for Schools and Program of Teacher Development. Paris: Division of Higher Education Unesco.

[23] Ki Hariyadi. 1985. The Among System: From the Education System to the Social System. Jogjakarta: Taman Siswa Luhur Council.

[24] Ki Soeratman. 1984. Basic Strategy for Development and Development of Taman Siswa. Yogyakarta: Taman Siswa Luhur Assembly. 
[25] Knight Peter, 2006. A systemic approach to professional development: learning as practice. Lancaster University, Lancaster, La14YL, UK. http://www.asian-efl-journal.com/Sept_06_ dn.php. Accessed Friday, January 14, 2011 at 19:35

[26] Liisa Postareff, Sari Lindblom-Yla, Anne Nevgi. 2007: The Effect of Pedagogical Training on Teaching in Higher Education. Journal of Teaching and Teacher Education 23 (2007) 557-571. (http://www.elsevier.com/ locate / tate). E-mail: Tate @ cardiff. ac.uk accessed Sunday, January $2,2011$.

[27] Loughran \& Berry. 2005. Modeling by teacher educators. Journal Teaching and Teacher Education. 21. 193-203.

[28] Manan. 2003. Tradition in Javanese Cultural Perspective. Yogyakarta: Tiara Wacana.

[29] Mayer, Richard E. 2008. Learning and Instruction Second Edition. New Jersey: Pearson Merrill Prentice Hall.

[30] Putu Sutrisno. 2010. Learning Theory. (http://putusutrisna.blogspot.com/2010/11/ theorylearning-robert-gagne.html)

[31] Reigeluth, CM and Alison A. Carr-Chellman. 2001. Intructional-Design Theories and Models Building a Common Knowledge Base, Volume III. New Jersey: Lawrence Erlbaum Associates Publishers.

[32] Richey, Rita C. \& Klein, James D. 2007. Design and Development Research Methods, Strategies, and Issues. New Jersey: Lawrence Erlbaum Associates Publishers.

[33] Robert Rueda, Lilia D. Monzo. 2002. Apprenticeship for teaching: professional development issues surrounding the collaborative relationship between teachers and paraeducators. Journal Teaching and Teacher Education 18 (2002) 503-521. (http: //www.elsevier. com / locate / tate). E-mail: Tate @ cardiff. ac.uk accessed Tuesday 4 January 2011 at 20.30

[34] Rychen and Salganik, LH 2003. (www.oecd.org/edu/statistics/desecowww. Deseco.admin.ch) (2003) DS Rychen and LH Salganik (eds.)

[35] Salim and Salim. 2001. Competence Transformation, Psychological Review. Jakarta: PT Raja Grafindo.

[36] Seels, Barbara B., Richey, Rita C. 2004. Educational Technology. New Jersey: Lawrence Erlbaum Associates Publishers.

[37] Slavin, Robert E. 2000. Cooperative Learning Theory, Research, and Practice. Needham Heights: Ellyn and Bacon.

[38] Smaldino, Sharon E. et.al. 2005. Instructional Technology and Media for Learning. New Jersey: Pearson Merrill Prentice Hall.

[39] Sugiyono. 2006. Quantitative Research Methods, Qualitative and R \& D. Bandung: Alfabeta.

[40] West CK, Farmer JA, Wolf PM 1991. Instructional Design Implication From Cognitive Science. Needham Heights: by Ellyn and Bacon.

[41] Hero. 2002. Educational Psychology. Jakarta: PT Raja Grafindo. 